\title{
Double indirect object marking in Spanish and Italian
}

Stark, Elisabeth ; Dufter, Andreas

Posted at the Zurich Open Repository and Archive, University of Zurich ZORA URL: https://doi.org/10.5167/uzh-10753

Book Section

Published Version

Originally published at:

Stark, Elisabeth; Dufter, Andreas (2008). Double indirect object marking in Spanish and Italian. In: Seoana, Elena; López-Couso, Maria José. Theoretical and empirical issues in grammaticalization. Amsterdam/Philadelphia: Benjamins, 111-129. 


\section{Theoretical and Empirical Issues}

\section{in Grammaticalization}

Edited by

Elena Seoane

María José López-Couso

University of Santiago de Compostela

In collaboration with

Teresa Fanego 
The paper used in this publication meets the minimum requirements of American National Standard for Information Sciences - Permanence of Paper for Printed Library Materials, ANSI z39.48-1984.

\section{Library of Congress Cataloging-in-Publication Data}

Theoretical and empirical issues in grammaticalization / edited by Elena Seoane and María José López-Couso.

p. $\mathrm{cm}$. (Typological Studies in Language, ISSN 0167-7373; v. 77)

Includes bibliographical references and indexes.

1. Grammar, Comparative and general--Grammaticalization. I. Seoane, Elena. II. LópezCouso, María José.

P299.G73T 492008

$415-$-dc22 2008009809

ISBN 9789027229892 (Hb; alk. paper) - ISBN 9789027229915 (set : alk. paper)

() 2008 - John Benjamins B.V.

No part of this book may be reproduced in any form, by print, photoprint, microfilm, or any other means, without written permission from the publisher.

John Benjamins Publishing Co. P.O. Box $36224 \cdot 1020$ ME Amsterdam · The Netherlands John Benjamins North America · P.O. Box 27519 · Philadelphia PA 19118-0519 • USA

\section{Table of contents}

Address list

\section{Preface}

Introduction: Further reflections on grammaticalization Elena Seoane and María José López-Couso

Swedish $m a ̊$ and the (de)grammaticalization debate Peter Andersson

"Where grammar and lexis meet": Composite predicates in English Laurel J. Brinton

On the grammaticalization and (inter)subjectivity of evidential

(semi-)auxiliaries in Spanish

Bert Cornillie

Semantic, syntactic and constructional restrictions in the diachronic rise of modal particles in German: A corpus-based study on the

formation of a grammaticalization channel Gabriele Diewald and Gisella Ferraresi

Double indirect object marking in Spanish and Italian Andreas Dufter and Elisabeth Stark

The emergence of particle clusters in Dutch: Grammaticalization under adverse conditions

$$
\text { Jack Hoeksema }
$$

Antigrammaticalization, antimorphologization and the case of Tura Dmitry Idiatov

Can grammaticalization be parameterized? Jurgen Klausenburger

Possessive adjectives as a source of intensifiers Ekkehard König and Letizia Vezzosi

Information structure and grammaticalization Christian Lehmann 
From speech-situation evocation to hypotaxis: The case of Latin quamvis 'although'

Torsten Leuschner

Grammaticalization waves. The Russian subjunctive mood and person/number marking

Jens Nørgård-Sørensen

Discourse frequency and the collapse of the adposition vs. affix distinction in Lakota

Regina Pustet

On the grammaticalization of the Spanish expression puede que

María José Rodríguez Espiñeira and Belén López Meirama

On the history and present behaviour of subordinating that with adverbial conjunctions in English

Günter Rohdenburg

The regrammaticalization of linking elements in German Heide Wegener

Author index

Language index

361

Subject index

\section{Double indirect object marking in Spanish and Italian*}

\author{
Andreas Dufter and Elisabeth Stark \\ University of Munich (LMU) and University of Zurich
}

The emergence of doubly marked indirect objects in Spanish and Italian might seem to constitute another example of parallel grammatical evolution in Romance. However, whereas indirect object doubling in contemporary Spanish is obligatory in many cases and always possible elsewhere, it is highly constrained in Italian, both with respect to linguistic and extra-linguistic factors. This article investigates the distribution of indirect object doubling with several verbs of high frequency in Italian and Spanish, analysing contemporary spoken varieties as well as diachronic corpora. We argue that, while in Spanish the overall frequency of clitic-doubling has shown a steady increase since medieval times, for pronominal indirect objects, the factors favouring double object marking have remained surprisingly stable over time. In Italian, by contrast, indirect object doubling has become restricted to certain prototypical contexts of occurrence.

\section{Introduction}

As closely related Romance languages, Spanish and Italian share a large number of grammatical properties. Some of these are inherited from Vulgar Latin; others, however, constitute independent innovations, often with surprisingly parallel outcomes. In particular, both languages have developed two sets of pronominal object expressions: clitic pronouns, which are generally constrained to occurrences adjacent to a verb, and strong pronouns, which can be found in a wider range of syntactic environments. Indirect objects in contemporary Spanish and Italian can be overtly expressed by a clitic alone, as illustrated in (1a) and (2a) below. In addition to this minimal marking, both languages permit strong object pronouns to function as indirect object arguments, preceded by the case-marking preposition

* We are grateful to Concepción Company Company, Daniel Hole, Wulf Oesterreicher and Cinzia Russi, as well as to two anonymous reviewers, for their many valuable comments, and to the STABLAB at the University of Munich (LMU) for statistical advice. The usual disclaimers apply. 
a. With strong pronominal indirect objects, however, an interesting difference between Spanish and Italian can be observed: in all varieties of Present-day Spanish these pronominal objects require the presence of an additional co-indexed indirect object clitic, irrespective of their position before or after the finite verb. Therefore, (1b) and (1c) are grammatical, whereas (1d) and (1e) are not. In Italian, however, double pronominal indirect object marking appears to be avoided in formal and written registers (cf. (2b) and (2c) below). This was perhaps most concisely formulated in a squib by Cortelazzo (1984) entitled "Perché 'a mí me gusta' sì e 'a me mi piace' no?" ('Why A mi me gusta yes and $A$ me mi piace no?'). In contrast to Spanish, Standard Italian does permit single prepositional indirect object marking with strong pronouns, as in (2d) and (2e).

(1) Spanish

$$
\begin{array}{ll}
\text { a. } & \text { ge gusta. } \\
\text { me.cL pleases }
\end{array}
$$

b. A mí me gusta.

to me.pron me.cl pleases

c. Me gusta a mí.

me.cl pleases to me.Pron

d. ${ }^{*} A$ mí gusta.

to me.Pron pleases

e. *Gusta a mí.

pleases to me.Pron 'I like it.'

(2) Italian

a. Mi piace.

me.cl pleases

b. 'A me mi piace. ${ }^{1}$

to me.Pron me.cl pleases

c. 'Mi piace a me. me.cL pleases to me.Pron

d. A me piace. to me.PRON pleases

e. Piace a me. pleases to me.Pron 'I like it.'

1. For the sake of convenience, we note the limited acceptability of (2b) and (2c) with a question mark, without thereby committing ourselves to any judgement about grammaticality.
With lexical indirect objects, clitic-doubling is also found more often in Spanish than in Italian, and has become obligatory for indirect objects appearing preverbally, as in (3a). For postverbal indirect objects, as in (3b), recent work (cf. Becerra Bascuñán 2006; Company Company 2006) shows that double marking is steadily gaining ground as well, and predominates over single prepositional indirect objects overwhelmingly in varieties of American Spanish. By contrast, the presence of a co-indexed clitic is always optional in Italian, and is mostly restricted to contextually marked constructions, such as clause-external, dislocated indirect objects, as in (4) (possibly with an additional intonational break, indicated by a comma; cf. Benincà et al. 1991:133-138)

(3) Spanish

a. A María ??(le) gusta.

to Mary her.cL pleases

b. ?(Le) gusta a María. ${ }^{2}$

her.CL pleases to Mary

'Mary likes it.'

(4) Italian

a. A Maria, le/gli piace. ${ }^{3}$

to Mary her.cL pleases

b. Le/Gli piace, a Maria.

her.cL pleases to Mary

'Mary likes it.'

The data presented so far suggest that, with prepositional indirect objects, cliticdoubling is highly restricted in Present-day Standard Italian, whereas it is unmarked in all contemporary varieties of Spanish. However, grammatical descriptions of the two languages tend to provide somewhat vague - and at times, incompatible - accounts of indirect object marking variants. In particular, it has been claimed for Spanish that preverbal pronominal doubling, as in (1b), is restricted to contrastive indirect objects (Real Academia Española 1973: Section 3.10.4). With respect to indirect objects in general, Fernández Soriano (1999:1246) maintains that clitic-doubling occurs frequently in Spanish, and especially so with strong

2. For some native speakers at least, Gusta a María is as unacceptable as A María gusta. Notice, however, that the former construction type continues to be admitted by descriptive grammars and is solidly attested in corpora of contemporary Spanish, at least with some verbs which govern indirect objects (e.g. Juan regaló un libro a su novia 'Juan offered a book to his girlfriend' cited by Company Company 2006: 535).

3. The variation indicated in example ( $4 \mathrm{a}$ ) between the (normative) feminine indirect object clitic $l e$, reflecting gender concord, and the masculine indirect object clitic $g l i$ is widespread (cf. Section 4 below). 
pronouns, whereas it is impossible in Italian. On the other hand, indirect object clitic doubling has repeatedly been classified as a characteristic of spoken Italian in general or of 'advanced' varieties of Italian (italiano avanzato) which presumably foreshadow future stages of the standard language. Following Cortelazzo (1984:27), A me mi piace (2b) would become the only spontaneously produced form ("l'unica forma spontanea") in contemporary Italian. Many studies, notably Koch $(1993,1994)$, hypothesize that clitic-doubling of pronominal indirect objects in Italian is on its way towards grammaticalization. Italian would thus ultimately follow the same diachronic path as Spanish, though somewhat later than its Iberian sister.

The aim of the present contribution is to provide a corpus-based analysis of indirect object markings in Spanish and Italian. For this purpose, we analysed the indirect objects of a small set of highly frequent verbs presented in (5), which prototypically govern recipient or experiencer indirect objects.

$$
\begin{aligned}
& \text { (5) Spanish dar decir parecer gustar, encantar } \\
& \text { Italian dare dire sembrare, parere piacere } \\
& \text { 'give' 'say' 'seem' 'please' }
\end{aligned}
$$

Section 2 will examine the distribution of marking types illustrated in (1) through (4) in contemporary spoken Italian and Spanish. In particular, we will investigate if, and possibly how, the frequency of clitic-doubling co-varies with each of the following parameters: (i) the syntactic type of the prepositional indirect object (pronominal vs. lexical); (ii) its thematic role (experiencer vs. others); (iii) its position with respect to the governing verb (pre- vs. postverbal); and (iv) the register of the conversation (formal vs. informal). In Section 3, we will turn to the evolution of clitic indirect object doubling in both Spanish and Italian, presenting data from diachronic corpora as well as metalinguistic judgements on the topic. Section 4 , in turn, will be devoted to a general discussion which seeks to situate our synchronic and diachronic corpus results within a more general account of argument encoding in Romance. We will conclude in Section 5 by briefly addressing the question of whether the contemporary variation observed can be held to reflect grammaticalization in progress (cf. Kliffer 1998, with regard to clitic-doubling in French and Spanish).

\section{Indirect object marking in contemporary spoken Spanish and Italian}

Our examination of present-day spoken language is based on C-ORAL-ROM, a recently published corpus assembling comparable samples of conversation in four major Romance languages: Spanish, Portuguese, French and Italian (cf. Cresti and Moneglia 2005). For each of these languages, the corpus provides roughly
25-30 hours of transcribed speech containing approximately 300,000 words. All 193 Spanish conversations were recorded in Madrid, featuring 410 speakers of different regional and social backgrounds in a wide variety of situations. A similar sociolinguistic and situational diversity was aimed at in the Italian material, which consists of 204 conversations, most of them recorded in Florence, with a total of 451 participants. All recordings were made in natural environments and were transcribed orthographically, supplemented by prosodic annotations. In addition, each conversation is classified according to situation type and formality level. For our analysis, we examined all the occurrences of the verb lexemes given in (5) above which govern (overt) indirect objects. Objects dislocated from the core clause by a prosodic break were excluded.

As already noted, clause-internal indirect objects can be realized minimally, that is, by a clitic only, or non-minimally, by a prepositional phrase containing a strong pronoun or a lexical noun phrase, possibly in combination with a coindexed indirect object clitic. The overall distribution of the resulting indirect

\begin{tabular}{|c|c|c|c|c|c|}
\hline \multirow[t]{2}{*}{ Marking type } & & \multicolumn{2}{|c|}{ Spanish } & \multicolumn{2}{|c|}{ Italian } \\
\hline & & \# & $\%$ & \# & $\%$ \\
\hline $\begin{array}{l}\text { CL only } \\
\text { (It Mi piace) }\end{array}$ & (minimal) & 1,529 & 89.1 & 992 & 85.7 \\
\hline $\begin{array}{l}a \text { PRON only } \\
\text { (It } A \text { me piace) }\end{array}$ & (non-minimal single) & 0 & 0 & 29 & 2.5 \\
\hline $\begin{array}{l}\text { a NP only } \\
\text { (It } A \text { Maria piace) }\end{array}$ & (non-minimal single) & 13 & 0.8 & 82 & 7.1 \\
\hline $\begin{array}{l}\mathrm{CL}_{\mathrm{i}}+a \mathrm{PRON}_{\mathrm{i}} \\
\text { (It Le piace a lei) }\end{array}$ & (non-minimal double) & 126 & 7.3 & 48 & 4.1 \\
\hline $\begin{array}{l}\mathrm{CL}_{\mathrm{i}}+a \mathrm{NP}_{\mathrm{i}} \\
\text { (It Le piace a Maria) }\end{array}$ & (non-minimal double) & 48 & 2.8 & 7 & 0.6 \\
\hline Total & & 1,716 & 100 & 1,158 & 100 \\
\hline
\end{tabular}
object coding types for Spanish and Italian is given in Table 1.

Table 1. Indirect object marking types and their distribution (C-ORAL-ROM)

As Table 1 clearly illustrates, clitic-only marking predominates by a wide margin in both vernaculars. ${ }^{4}$ Interestingly, minimal codings occur even more often in Spanish than in Italian. Therefore, while the data presented in (1) to (4) suggest that the grammaticalization of double indirect object marking has progressed further in

4. The preponderance of non-lexical indirect objects in spoken discourse correlates with the overall rarity of lexical arguments in spoken discourse, predicted, on grammar-external grounds, by the theory of Preferred Argument Structure (cf. Du Bois 2003 for a synopsis). 
the spoken varieties of Spanish than in those of Italian, our overall findings do not support this hypothesis. With strong pronominal indirect objects, clitic-doubling is generalized in Spanish (7.3 per cent vs. zero), irrespective of focus structure, and predominates in Italian as well, with 4.1 as against 2.5 per cent (pace Real Academia Española 1973 and Fernández Soriano 1999). For lexical indirect objects, however, there is an interesting asymmetry: as with strong indirect object pronouns, double marking is preferred over single marking in Spanish ( $2.8 \mathrm{vs.} 0.8$ per cent), while its presence remains sporadic in Italian ( 0.6 per cent vs. 7.1 per cent).

A more fine-grained picture of indirect object coding tendencies is presented in Table 2, where token frequencies of indirect object marking types (clitic only, prepositional phrase only ( $a+$ noun phrase/strong pronoun) and double indirect object marking) are given for the individual verbs under consideration.

Table 2. Distribution of indirect object marking types for individual verbs (C-ORAL-ROM)

\begin{tabular}{llccc}
\hline & $\begin{array}{l}\text { minimal } \\
\text { \# cL only }\end{array}$ & \multicolumn{2}{c}{ non-minimal } & \# single \\
& & \# double & on-minimal markings \\
among all indirect objects & $(\mathbf{P P}+\mathbf{C L})$ & \\
\hline Sp dar & 328 & 7 & 41 & 12.8 \\
Sp decir & 825 & 4 & 33 & 4.3 \\
Sp parecer & 142 & 0 & 35 & 19.8 \\
Sp gustarlencantar & 234 & 2 & 65 & 22.3 \\
It dare & 191 & 63 & 8 & 27.1 \\
It dire & 493 & 24 & 11 & 6.6 \\
It sembrare/parere & 198 & 8 & 17 & 11.2 \\
It piacere & 110 & 16 & 19 & 24.1 \\
\hline
\end{tabular}

Clearly, the ratio of non-minimal indirect object marking differs considerably in accordance with the semantics of the governing verb. With the sole exception of verbs of giving ( $\mathrm{sp}$ dar, It dare), we find similar tendencies for both languages. In particular, clitic indirect object doubling occurs more often with verbs of liking (Sp gustar, encantar, It piacere) than with verbs of saying (Sp decir, It dire). ${ }^{5}$ More generally, doubling seems to be favoured by predicates selecting an experiencer indirect object. Among the verbs which function as prototypical raising verbs (Sp parecer, It parere and sembrare, all 'seem'), the higher frequency of nonminimal marking with parecer is very likely to be caused by its secondary uses as a psych predicate similar to gustar (cf. Sp ¿Qué te parece la idea? 'Do you like the

5. The differences in non-minimal marking frequency between $\mathrm{Sp}$ decir and It dire do not reach statistically significant levels (Fisher Exact test: $\mathrm{p}>0.05$ ). The same holds for Sp gustar and encantar compared to It piacere. idea?', cf. Torrego 1996). Even more telling are the heavily divergent rates of doubling with the prototypical verbs of giving: unlike its Italian cognate, $\mathrm{Sp}$ dar can be employed in a wide range of complex predicates which do not assign a recipient role to their indirect objects but rather an experiencer role. It is precisely in such cases that indirect object doubling occurs with dar, whereas all seven singlemarked strong pronominal or lexical indirect objects of dar encode a recipient. Some typical contexts of double marking are provided in (6).

(6) Contemporary spoken Spanish (C-ORAL-ROM)
a. a mi me daría
mucha vergüenza.
to me.Pron me.cL would.give much shame 'I would feel very ashamed.' (efamdl16)

b. iy a ti te da igual? and to you.Pron you.cL give.Prs.3sg the.same? 'And you don't mind?' (efamcv03)
c. a mí me da risa a veces.

to me.PRON me.CL give.PRs.3sg laughter sometimes 'It makes me laugh sometimes.' (efammn01)

For clitic-doubled strong indirect object pronouns - the most frequent double coding type in both languages - another pronounced tendency which emerges for the relative ordering of pronominal prepositional phrase and clitic is that both corpora contain significantly more instances of strong pronominal indirect objects preceding the governing finite verb (i.e. of the type $S p A$ mi me gusta (1b), It $A$ me mi piace (2b)) than of the reverse order (i.e. of the type Sp Me gusta a mí (1c), It Mi piace a $m e(2 \mathrm{c}))$. The relevant figures are given in Table 3 below.

Table 3. Position of doubled indirect object strong pronouns with respect to the verb (C-ORAL-ROM)

\begin{tabular}{lcl}
\hline & \# preverbal & \# postverbal \\
\hline Sp dar & 24 & 1 \\
Sp decir & 4 & 9 \\
Sp parecer & 28 & 7 \\
Sp gustar/encantar & 48 & 5 \\
It dare & 4 & 3 \\
It dire & 3 & 4 \\
It sembrare/parere & 11 & 6 \\
It piacere & 15 & 2 \\
\hline
\end{tabular}

Within doubly marked strong indirect object pronouns, the preference for preverbal instead of postverbal position is particularly strong with verbs of liking (Sp gustar, encantar, It piacere). The verbs which do not follow the general trend 
is the pair Sp decir and It dire 'say.' To test whether this distributional asymmetry co-varies with thematic role, we searched all clauses containing both a strong pronominal indirect object (such as Sp a mi, a ti, It $a$ me, a te) and a co-indexed indirect object clitic with verbs other than those previously considered. For both languages, tokens of the two relative orderings were counted separately for experiencer and non-experiencer indirect objects. The resulting percentages in Table 4 imply that the preference for preverbal double marking is limited to experiencer indirect objects (governed by verbs such as Sp aburrir 'bore,' sorprender 'surprise,' It preoccupare 'bother', interessare 'be of interest'), while both orderings are equally common for the other semantic types (see Section 4 below for discussion).

Table 4. Position of doubled indirect object strong pronouns with respect to other verbs than those analysed in Table 3 (C-ORAL-ROM)

\begin{tabular}{lll}
\hline & $\%$ preverbal & \% postverbal \\
\hline Sp other experiencer IOs & 76 & 24 \\
Sp other non-experiencer IOs & 54 & 46 \\
It other experiencer IOs & 81 & 19 \\
It other non-experiencer IOs & 50 & 50 \\
\hline
\end{tabular}

We turn next to the prevailing type of preverbal clitic-doubled strong experiencer pronouns, as in utterances such as Sp $A$ mi me gusta, cited in (1b), or It $A$ me mi piace (2b), which figure in the title of Cortelazzo (1984). Once again, Cortelazzo's choice of first person singular pronouns reflects a clear-cut distributional trend since, among all preverbal pronominal indirect object doublings, more than half of the indirect objects are first person singular. While the preponderance of first person singular pronouns is likely to constitute a characteristic feature of orality, there is another asymmetry in our data which does not derive from spoken communication in general. The data in Table 5 show that, within the most typical psych verbs (Sp gustar, encantar, It piacere), first person singular indirect objects are not only the most frequent category, but also significantly more prone to be doubly marked than other person-number combinations. ${ }^{6}$

Finally, Spanish and Italian appear to differ in the socio-stylistic value assigned to preverbal pronominal clitic-doubled indirect objects. At least for the verbs analysed in this paper, we did not find a significantly higher proportion of this type of construction in formal Spanish conversations, as opposed to informal ones (6.3 per cent vs. 5.3 per cent of all indirect object occurrences, respectively; Fisher Exact test: $\mathrm{p}=0.54) .^{7}$ By contrast, the type $A$ me mi piace appeared consid-

6. The preference for doubled clitics to occur with preverbal first person singular pronouns is also reported by Barrenechea and Orecchia (1970) for the spoken Spanish of Buenos Aires.

7. Cf., however, the register differences reported in Becerra Bascuñán (2006:140-141).
Table 5. Doubling of preverbal indirect object pronouns with the psych verbs $S p$ gustarlencantar, It piacere (C-ORAL-ROM)

\begin{tabular}{lccc}
\hline & 1sG & Other & Total \\
\hline Sp gustar/encantar & & & \\
\# preverbal IO PRONs & 38 & 10 & 48 \\
\# IO clitics & 172 & 115 & 287 \\
\% pronominal IO doubling & 22.1 & 8.7 & 16.7 \\
It piacere & & & \\
\# preverbal IO PRONs & 11 & 4 & 15 \\
\# IO clitics & 79 & 56 & 135 \\
\% pronominal IO doubling & 13.9 & 7.1 & 11.1 \\
\hline
\end{tabular}

erably more often in informal Italian speech than in formal registers (1.4 per cen vs. 0.4 per cent). Nevertheless, the few tokens observed do not permit us to draw any firm conclusions here.

Summarizing our results for indirect object marking in contemporary spoken language, we find that in general, minimal, clitic-only marking predominates in Spanish and Italian. Within the minority of non-minimal markings, both languages favour clitic-doubling over single marking with strong indirect object pronouns. For lexical indirect objects, by contrast, clitic-doubling is preferred in Spanish, but is marginal in Italian. Moreover, in both vernaculars, clitic-doubling is most likely to appear with preverbal pronominal indirect objects which encode experiencer arguments. Within this subclass of indirect object codings, first person singular experiencer arguments account for more than half of all pronominal indirect objects. On the whole, our findings are in line with Cortelazzo's (1984), since clitic-doubling is more restricted for indirect objects in Italian than in Spanish. However, we disagree with Cortelazzo precisely because of the special case referred to in the title of his paper. Irrespective of normative judgements, not only Sp $A$ mi me gusta, but also It $A$ me mi piace appear to represent prototypical cases of double indirect object marking. The following section will address the diachrony of indirect object codings in Italian and Spanish.

\section{The evolution of double indirect object marking}

Our investigation of change in Spanish indirect object codings is based on the Corpus del español (created by Mark Davies and searchable online at www.corpusdelespanol.org). This database comprises a 100,000,000-word collection of texts, organized by century, from Old Castilian to Present-day Spanish. Earlier descriptions of pronominal object marking, cited in Rini (1991), assumed a gradual transition from clitic-only to double pronominal codings, with additional 
strong object pronouns originating as disambiguating or emphatic devices (cf. Riiho 1988 for an in-depth historical investigation). However, single strong pronominal indirect objects, as in (7) below, are attested alongside clitic-only objects wel before clitic-doubled objects.

(7) Old Spanish
A mi
lo dizen,
ti dan
las orejadas.
to me.Pron it say.Prs.3PL to you.Pron give.PRs.3PL the ears

'To me they say it, upon your ears it falls.' (c. 1140, Cantar de Mio Cid, v.

3304; from Marcos Marín 1978:77)

In the present study, we concentrate on tracing the evolution of preverbal pronominal indirect object doubling, which, as noted above, constitutes by far the mos frequent type of double marking in present-day spoken language. This construction is also attested as early as in the Cantar de Mio Cid, but occurs with any significant frequency in the Corpus del español only in the fourteenth century. Although the number of occurrences of the construction is too low to lead to any definite conclusions, these occurrences do suggest a preference for doubling first person singular and/or experiencer indirect objects. Illustrative examples are cited in $(8 a-c)$.

(8) Old Spanish

a. a mí non me pesa.

to me.Pron not me.cL grieve.Prs.3sG

'It does not grieve me.' (c. 1140, Cantar de Mio Cid, v. 1480)

b. a mi me plazera.

to me.Pron me.cL please.FUT.3sG

'I will like it.' (c. 1335, Juan Manuel, Libro de las armas)

c. a Él le plaziendo, muriera.

to him.Pron him.cL like.GER die.FUT.3sG

'If He (God) likes it, he will die.' (1378-1406, Pero López de Ayala, Rimado de Palacio)

Unfortunately, the Corpus del español does not currently allow searches for nonadjacent clausemate expressions with an arbitrary number of words intervening, and hence we were unable to take into account systematically all occurrences of pronominal doubling. Therefore, we selected a prototypical subset of double indirect objects and limited our searches to combinations of $a$ mí and $m e$ (including its orthographic variant $a m i m e$ ) within the same clauses which function as arguments of decir, dar, parecer and gustar. ${ }^{8}$ For each of these verbs, we calculated the

8. Since Sp encantar 'please' occurs far less frequently in written than in contemporary spoken speech, we excluded it from consideration in our diachronic investigation. percentage of clitic-doubled a mí (or $a m i$ ) among all occurrences of $m e$, counting both preverbal and postverbal clitics, both orthographically bound and free. The resulting figures for written Spanish are provided in Table $6 .{ }^{9}$

Table 6. Percentage of doubling with first person singular indirect objects in written Spanish (Corpus del español)

\begin{tabular}{lcllcl}
\hline & 16th c. & 17th c. & 18th c. & 19th c. & 20th c. \\
\hline decir & 1.3 & 1.4 & 0.7 & 1.0 & 0.9 \\
dar & 3.0 & 2.2 & 2.6 & 3.6 & 2.7 \\
parecer & 10.1 & 7.7 & 6.2 & 5.6 & 5.5 \\
gustar & 0 & 0 & 9.4 & 10.8 & 6.9
\end{tabular}

Given the claim that indirect object clitic-doubling has been undergoing a process of grammaticalization in Modern Spanish, one might expect the proportion of clitic-doubled a mí to grow over time. However, the data from the Corpus del español show precisely the opposite development for all four of the verbs considered. Even more noteworthy is the fact that the relative proneness of the individual verbs to take clitic-doubled pronouns remains constant throughout. For all the centuries in which decir and parecer are attested with clitic-doubled pronominal indirect objects, the proportion of clitic-doubling is much higher with parecer than with decir. As Table 6 shows, similar observations hold for the other pairings of verbs. The somewhat delayed clitic-doubling with gustar can be explained by the fact that, in older stages of Spanish, this verb was construed transitively (see Melis 1998 for a detailed account). In the older argument structure, the experiencer was coded as the subject and the stimulus as direct object, a usage now considered archaic. While one has to wait until the second half of the eighteenth century for the first attestations of gustar with experiencer indirect objects, clitic-doubling is rapidly gaining acceptance with this new argument coding.

Turning now to twentieth-century Spanish, an important difference in the frequency of clitic-doubling can be found when comparing written and oral usages in the Corpus del español. In Table 7, the figures already given in Table 6 above for the written language are repeated for convenience, alongside which the respective percentages for spoken Spanish in the same corpus are given. As can be seen, with all four verbs considered, double first person singular indirect objects are much more likely to occur in spoken than in written Spanish (cf. also Becerra Bascuñán 2006: 112-120).

For Italian, tracing the historical evolution of double indirect object marking turns out to be more difficult, as diachronic corpora comparable to the Corpus del

9. Note that, for the twentieth century, the Corpus del español provides separate subsets of transcribed oral and written Spanish, including a wide range of American varieties. 
Table 7. Percentage of doubling with first person singular indirect objects in twentieth century Spanish (Corpus del español)

\begin{tabular}{llc}
\hline & written & spoken \\
\hline decir & 0.9 & 1.7 \\
dar & 2.7 & 6.6 \\
parecer & 5.5 & 14.6 \\
gustar & 6.9 & 13.9 \\
\hline
\end{tabular}

español are not currently available. For this reason, our description will be based on the data presented and discussed in D'Achille (1990a, 1990b). This author analyses three different registers, ${ }^{10}$ namely (i) 'near spoken' (e.g. testimonies), (ii) 'normal prose' and (iii) 'elevated style,' from the earliest Italian texts up to the eighteenth century, distributed across five periods. These five periods follow key moments in Italian linguistic history (cf. D'Achille 1990a: 20-22):

a. The very first attestation until 1250 .

b. Old Italian (1250-1375, Boccaccio's death).

c. The period before the standardization in Bembo's Prose della volgar lingua (1375-1525).

d. The period before the first edition of the Vocabolario of the Accademia della Crusca (1525-1612).

e. The period from 1612 to 1799 , before the use of spoken or near-spoken language in a written, even highly literary style, is first admitted and subsequently extended, with the arrival of realism, verism and so on.

D'Achille (1990a) examines those syntactic phenomena which are considered typical of spoken communication and which have been disapproved of repeatedly in prescriptive and poetological discourse. Dislocation constructions feature prominently among these phenomena. This implies, at least with respect to linear order, the same type of non-minimal indirect object marking illustrated in (2b), (2c) and (4). Table 8 below gives an overall impression of the quantitative development of the attested left- and right-dislocations of indirect objects. Even though Table 8 does not provide specific information about the evolution of the type $A$ me $m$ piace, it shows a slight decrease of left-dislocated indirect objects over time. This decline is particularly sharp in the highest register, and less so in the lowest, which suggests an increasing disfavouring of left-dislocated indirect objects in Standard Italian. Moreover, and crucially in our context, double indirect object marking is attested in various subtypes from the very beginning of Italoromance. Two pieces of literary evidence are adduced in $(9 a-b)$ below.

10. D'Achille's classification parameters are 'private vs. public communication,' 'spontaneity', 'phoneticity,' 'hearer-directedness' and 'expressivity'
Table 8. Evolution of double indirect object marking in Italian across different registers (D'Achille 1990a:195)

\begin{tabular}{|c|c|c|c|c|c|c|c|c|c|}
\hline & \multirow{2}{*}{$\begin{array}{l}-1250 \\
\#\end{array}$} & \multicolumn{2}{|c|}{$1250-1375$} & \multicolumn{2}{|c|}{$1375-1525$} & \multicolumn{2}{|c|}{$1525-1612$} & \multicolumn{2}{|c|}{$1612-1799$} \\
\hline & & \# & $\%$ & \# & $\%$ & \# & $\%$ & \# & $\%$ \\
\hline \multicolumn{10}{|c|}{ preverbal (left-dislocated) indirect object + CL } \\
\hline near spoken & 1 & 6 & 50.0 & 10 & 9.4 & 17 & 13.1 & 32 & 15.4 \\
\hline normal prose & 0 & 20 & 19.6 & 24 & 15.0 & 18 & 16.2 & 16 & 8.2 \\
\hline elevated style & 0 & 13 & 25.0 & 19 & 22.4 & 4 & 10.0 & 2 & 2.3 \\
\hline \multicolumn{10}{|c|}{ postverbal (right-dislocated) indirect object $+\mathrm{CL}$} \\
\hline near spoken & 0 & 3 & 18.8 & 11 & 30.6 & 19 & 47.5 & 9 & 33.3 \\
\hline normal prose & 0 & 5 & 20.8 & 6 & 17.6 & 13 & 30.2 & 7 & 10.4 \\
\hline elevated style & 0 & 3 & 16.7 & 0 & 0 & 1 & 50.0 & 0 & 0 \\
\hline
\end{tabular}

(9) Old Italian

a. Calandrino, se la prima gli $\mathrm{i}_{\mathrm{i}}$ era paruta Calandrino if the first.one him.cL be.PST.3sg appeared.PTCP amara, questa gli $_{\mathrm{i}}$ parve amarissima.

bitter this.one him.cL appear.PST.3sg extremely.bitter

'Calandrino, if the first one seemed bitter to him, this one seemed extremely bitter to him.' (c. 1350, Boccaccio, Decameron VIII, 6)

b. A voi $i_{1}$ mesere Petro amico spetiale, lo signore Deo to you.Pron sir Peter friend special the lord God $\boldsymbol{v e}_{\mathrm{i}}$ dia la sua gratia $e$ bona ventura. you.cl give.sBjv.3sg the his grace and good luck 'To you, Sir Peter, my special friend, shall the Lord give his grace and good luck.' (1243, Guido Faba, Parlamenti)

Both (9a) and (9b) show indirect object left-dislocations, in the former case with a proper name (i.e. a noun phrase), in the latter with a strong pronoun in a prepositional phrase (cf. examples (4a) and (2b) for Present-day Standard Italian). Furthermore, D'Achille (1990a:291) explicitly mentions the type A me mi piace, which - contrary to other types of dislocations - seems to decrease continuously over time in all three registers.

A look at some metalinguistic judgements from the Renaissance period of the Italian questione della lingua, that is, academic discussion about the appropriate variety to be chosen for high literature, illustrates the restrictive normative attitude towards apparently widespread doubling constructions. The principal criticism is that they are stylistically superfluous, anomalous and so on, especially pronominal doubling. An instance of this is found in Pietro Bembo's Prose della volgar lingua (1525; for further details see D'Achille 1990a:100-103). At the same time, the structural similarities between the Italian and Spanish constructions and the 
different frequencies and degrees of markedness are described in the metalinguistic literature as early as 1560 by the Napolitan author Giovan Mario Alessandri in his Paragone della lingua toscana et castigliana:

$\mathrm{Si}$ raddoppiano molto frequentemente due pronomi in un medesimo caso obliquo, dove è forza ch'uno d'essi abbandi: Siendome possibile a mi, a sì, Dios a mi me salve, a mi no me pesa tanto [...]. Rarissimo è questo modo di dire a' Toscani, e si fugge assai come cosa soperchia; a' Castigliani è frequentissimo et proprio, ma non di maniera che 'l porre i semplici non sia molto più in uso.

(D'Achille 1990a: 106)

[Very often two pronouns are doubled for one and the same oblique case, so that automatically one of them becomes superfluous: it me being possible for me, for one, God for me me rescues, to me me it is not so difficult [...]. This way of saying is very infrequent with the Tuscans, and it is avoided as a superfluous thing; it is very frequent and typical with the Castilians, but still the single pronoun is used much more.]

Finally, Radtke (1987) points out that the type A me mi piace (in both the present and the past tense) is given as the unmarked form in a seventeenth century handbook for learners of Italian (Fabre 1626). Taken together, all this evidence suggests that the construction has been attested since the very beginning of Italoromance writings and that it had a continuous history until Present-day Standard Italian, being marked as non-standard since the sixteenth century. We might also bear in mind that both recipients and experiencers are among the first attestations, as can be seen in the examples under (9) above.

\section{Discussion}

At least since Givón (1976), grammaticalization theory has amply demonstrated a crosslinguistic evolutionary trend for anaphoric pronouns co-indexed with clauseexternal topical verb arguments. Over time, these pronouns are reduced to verbal clitics and, ultimately, agreement affixes. At the same time, the dislocated topics which originally served as antecedents of the clause-internal pronouns become gradually integrated into the clause. In addition, Givón (1976:152, 1984:139) formulates several hierarchies for the likelihood of arguments to encode topical referents. Unlike direct objects, indirect objects tend to rank high on these scales of topic affinity, since most of them are definite and refer to animate and, in particular, human participants directly involved in the event denoted by the proposition. Among human referents, it is the addressee and, even more so, the speaker him- self who enjoy highest topic affinity. ${ }^{11}$ Grammaticalization theory therefore predicts that indirect objects, and above all first person pronouns, will develop more rapidly into verbal clitics and affixes than direct object pronouns. This general prediction is indeed borne out in the evolution of Romance (cf. Koch 1993).

When we consider the degree of grammaticalization of Spanish and Italian indirect object clitics, overall frequencies suggest that Spanish has progressed further than Italian (cf. Silva-Corvalán 1984). Likewise, traditional accounts (cf. Llorente Maldonado de Guevara and Mondéjar 1974), together with analyses informed by modern syntactic theory, tend to consider Spanish object clitics to be further advanced on their way toward morphologization (cf. Enrique-Arias 2000 and Franco 2000, among others; for a critical discussion, cf. García-Miguel 1991). Moreover, Spanish indirect object clitic doubling is acquired early and almost without any errors by children (Torrens and Wexler 2000). With respect to semantics and pragmatics, the indirect object clitics $l e$ and les (and their combinatorial variant $s e$ ) of Standard Spanish do not exhibit any special restrictions on doubling (GutiérrezRexach 2003), which sets them apart from direct object clitics. Viewed from a broader perspective, the preponderance of indirect object double marking over doubling of direct objects may be added to a number of converging arguments for an overall trend toward 'dative strengthening' in the history of Spanish (Company Company 2001). ${ }^{12}$

With Italian, we saw in Section 3 a global decrease of indirect object doubling and its exclusion from literary usage. The only major surviving types, at least in informal spoken Italian, are found precisely in those constructions where experiential involvement is highest, namely those in which speakers express emotions and subjective preferences or, conversely, aversions.

Furthermore, Spanish and Italian have witnessed a remarkable loss of semantic distinctions in indirect object clitics. Both in the singular and in the plural, gender distinctions have been lost in Spanish (cf. Sp le and its morphophonological variant $s e$ 'him.DAT, her.DAT'), and are preserved only in Standard Italian (cf. It gli 'him.DAT' vs. le 'her.DAT,' cf. (4b)), whilst regularly collapsed in informal spoken varieties of the language, which generalize the masculine singular form gli.

11. However, we found several instances of utterance-initial $\mathrm{Sp} A$ mi $m e[\ldots]$ as well as It $A m e$ $m i[\ldots]$, which are not attributable to topic-marking, since the discourse referent is the already introduced currently active speaker. In these cases, doubling of object pronouns seems to be employed as a strategy to obtain the next turn in lively conversation.

12. Note that this trend is by no means restricted to the standard variety, but emerges most strikingly in the evolution of non-standard systems of clitic object marking: while leismo, the appearance of dative clitics for direct objects, has become more and more widespread, reverse phenomena of accusative clitics encoding indirect objects (so-called laismo and loísmo) are restricted to a handful of rural dialects (cf. Fernández-Ordóñez 1999, and references cited there). 
Moreover, colloquial Italian also employs gli instead of standard loro for plural indirect objects. A similar observation can be made for Spanish, where no number distinction is expressed by $s e$, and the singular le has gradually come to be preferred with plural objects over plural les in many varieties (cf. Company Company 2006: Section 6.6.2). Whereas earlier discussions of incipient object agreement in Romance take this reduction of categorical distinctions as evidence against a full-blown agreement system in Spanish (Heger 1966:37), more recent accounts interpret the weakening of gender and number distinctions as 'depronominalization,' i.e. loss of referential autonomy (Company Company 2001:23-25). For lexical objects in Spanish, the increase in double marking of indirect objects parallels the rise of non-minimal, prepositional marking of direct objects, as in Sp Veo a Juan 'I see John', where the direct object is formally indistinguishable from an indirect object (cf. Company Company 2003 for the interrelatedness of changes in object codings). With pronominal indirect objects, however, double marking seems to have functioned predominantly to mark thematic role rather than to encode syntactic case or definiteness since its earliest attestations (cf. Montrul 1996; see Suñer 1999 for a different view). ${ }^{13}$

\section{Conclusion}

Our study of the synchronic patterning and the diachrony of double indirect object marking in Spanish and Italian has revealed that clitic-only marking continues to be the most frequently used type, even in informal spoken language. While our corpus of contemporary spoken Italian does provide us with the very same types of non-minimal indirect object marking which appear in spoken Spanish, only the prototypical case of first person experiencer indirect object shows roughly comparable rates of double marking in both languages. In all other cases, Spanish speakers appear to double indirect objects more readily than Italian speakers, who tend to restrict doubling by and large to informal situation types. By contrast, Spanish favours indirect object doubling in all registers of speech, though double pronominal marking is much less likely to be employed in writing. This asymmetry can be explained by universal characteristics of oral communication (cf. Koch and Oesterreicher 1990). Therefore, it does not appear justified to con-

13. For a corpus of contemporary written Spanish, containing both journalistic and literary texts, Koontz-Garboden (2002) reports that only animacy, but not definiteness, favours indirect exts object doubling to a significant extent. Since experiencer arguments are necessarily animate, whereas they need not be definite, we may interpret this finding as an additional indication of the predominantly role-marking function of doubling. sider spoken varieties of Spanish or Italian to be further advanced towards the grammaticalization of object clitics into agreement markers.

With respect to linguistic factors influencing the likelihood of double indirect object pronouns, the evolution of Spanish does not provide evidence for any change at all. In particular, we failed to find a marked increase in clitic-doubling for the most frequent type of pronominal indirect objects. It is the very same constellations of first person pronominal indirect objects and experiencer predicates that appear to favour clitic doubling from the outset. From a more comprehensive perspective, taking the evolution of variation into account, Spanish appears more conservative than previously assumed. Similar claims of diachronic stability have been made for the history of Italian indirect object doubling (cf. Benincà 1986:231). However, the Italian corpus evidence suggests that the dropping of 'redundant' pronouns imposed by standardization has considerably restricted double marking not only in its sociolinguistic distribution, but also with respect to linguistic contexts. Therefore, we are inclined to be skeptical about the widely assumed trend toward grammaticalization for indirect object clitics in Romance.

\section{Abbreviations}

$\begin{array}{llll}3 & \text { third person } & \text { PRON } & \text { strong pronoun } \\ \text { CL } & \text { clitic pronoun } & \text { PRS } & \text { present } \\ \text { DAT } & \text { dative } & \text { PST } & \text { past } \\ \text { FUT } & \text { future } & \text { PTCP } & \text { participle } \\ \text { GER } & \text { gerund } & \text { SBJV } & \text { subjunctive } \\ \text { IO } & \text { indirect object } & \text { SG } & \text { singular }\end{array}$

\section{References}

Barrenechea, Ana María \& Teresa Orecchia. 1970. La duplicación de objetos directos e indirectos en el español hablado en Buenos Aires. Romance Philology 24: 58-83.

Becerra Bascuñán, Silvia. 2006. Estudio diacrónico y sincrónico del objeto indirecto en el español peninsular y de América [Études Romanes 57]. Copenhagen: Tusculanum.

Benincà, Paola. 1986. Il lato sinistro della frase italiana. Balkan-Archiv 11: 213-243.

Benincà, Paola, Giampaolo Salvi \& Lorenza Frison. 1991. L'ordine degli elementi della frase ele costruzioni marcate. In Lorenzo Renzi (ed.), Grande grammatica italiana di consultazione. Vol. I: La frase. I sintagmi nominale e preposizionale, 115-225. Bologna: Il Mulino.

Company Company, Concepción. 2001. Multiple dative-marking grammaticalization: Spanish as a special kind of primary object language. Studies in Language 25: 1-47. 
Company Company, Concepción. 2003. Transitivity and grammaticalization of object. The diachronic struggle of direct and indirect object in Spanish. In Giuliana Fiorentino (ed.), Romance objects. Transitivity in Romance languages [Empirical Approaches to Language Typology 27], 217-260. Berlin: Mouton de Gruyter.

Company Company, Concepción. 2006. El objeto indirecto. In Concepción Company Company (ed.), Sintaxis histórica de la lengua española. Vol. I: La frase verbal, 479-574. México: Universidad Nacional Autónoma de México y Fondo de Cultura Económica.

Cortelazzo, Manlio. 1984. Perché 'a mí me gusta' sì e 'a me mi piace' no? In Günter Holtus \& Edgar Radtke (eds.), Umgangssprache in der Iberoromania. Festschrift für Heinz Kröll, 25-28. Tübingen: Narr.

Cresti, Emanuela \& Massimo Moneglia (eds.). 2005. C-ORAL-ROM. Integrated reference corpora for spoken Romance languages [Studies in Corpus Linguistics 15]. Amsterdam: John Benjamins.

D’Achille, Paolo. 1990a. Sintassi del parlato e tradizione scritta della linguaitaliana. Analisi di testi dalle origini al secolo XVIII. Roma: Bonacci.

D'Achille, Paolo. 1990b. I fenomeni di 'tematizzazione' di fronte alle codificazione cinquecentesca. In Emanuele Banfi \& Patrizia Cordin (eds.), Storia dell'italiano e forme dellitalianizzazione. Atti del XXIII congresso internazionale di studi della Società di Linguistica Italiana (SLI). Trento - Rovereto, 18-20 maggio 1989, 283-294. Roma: Bulzoni.

Davies, Mark. Not dated. Corpus del español. <www.corpusdelespanol.org $>$.

Du Bois, John W. 2003. Argument structure: Grammar in use. In John W. Du Bois, Lorraine E. Kumpf \& William J. Ashby (eds.), Preferred Argument Structure: Grammar as architecture for function [Studies in Discourse and Grammar 14], 11-60. Amsterdam: John Benjamins.

Enrique-Arias, Andrés. 2000. Spanish object agreement markers and the typology of object agreement morphology. In Steven Dworkin \& Dieter Wanner (eds.), New approaches to old problems. Issues in Romance historical linguistics [Current Issues in Linguistic Theory 210], 149-164. Amsterdam: John Benjamins.

Fabre, Antoine. 1626. Grammaire pour aprendre les langues italienne, françoise, et espagnole. Roma: Corbelletti.

Fernández Soriano, Olga. 1999. El pronombre personal. Formas y distribuciones. Pronombres átonos y tónicos. In Ignacio Bosque \& Violeta Demonte (eds.), Gramática descriptiva de la lengua española. Vol. I, 1209-1273. Madrid: Espasa Calpe.

Fernández-Ordóñez, Inés. 1999. Leísmo, laísmo y loísmo. In Ignacio Bosque \& Violeta Demonte (eds.), Gramática descriptiva de la lengua española. Vol. I, 1317-1397. Madrid: Espasa Calpe.

Franco, Jon. 2000. Agreement as a continuum: The case of Spanish pronominal clitics. In Frits Beukema \& Marcel den Dikken (eds.), Clitic phenomena in European languages [Linguistik Aktuell/Linguistics Today 30], 147-189. Amsterdam: John Benjamins.

García-Miguel, José María. 1991. La duplicación de complemento directo e indirecto como concordancia. Verba 18: 375-410.

Givón, Talmy. 1976. Topic, pronoun and grammatical agreement. In Charles N. Li (ed.), Subject and topic, 149-188. New York NY: Academic Press.

Givón, Talmy. 1984. Syntax. A functional-typological introduction. Vol. I. Amsterdam: John Benjamins.

Gutiérrez-Rexach, Javier. 2003. Constraint interaction at the semantics/pragmatics interface: The case of clitic doubling. In Katarzyna M. Jaszczolt \& Ken Turner (eds.), Meaning through language contrast. Vol. I [Pragmatics and Beyond, New Series 99], 335-354. Amsterdam: John Benjamins.

Heger, Klaus. 1966. La conjugaison objective en français et en espagnol. Langages 3: 19-39.
Kliffer, Michael D. 1998. Clitic duplication in western Romance. A case of grammaticalization. LACUS Forum 24: 421-434.

Koch, Peter. 1993. Le 'chinook' roman face à l'empirie. Y a-t-il une conjugaison objective en français, en italien et en espagnol et une conjugaison subjective prédéterminante en français? In Gerold Hilty (ed.), Actes du XXe congrès international de Linguistique et Philologie Romanes. Vol. III, 169-190. Tübingen: Francke.

Koch, Peter. 1994. L'italiano va verso una coniugazione oggettiva? In Günter Holtus \& Edgar Radtke (eds.), Sprachprognostik und das 'italiano di domani.' Prospettive per una linguistica 'prognostica' [Tübinger Beiträge zur Linguistik 384], 175-194. Tübingen: Narr.

Koch, Peter \& Wulf Oesterreicher. 1990. Gesprochene Sprache in der Romania: Französisch, Italienisch, Spanisch. [Romanistische Arbeitshefte 31]. Tübingen: Niemeyer.

Koontz-Garboden, Andrew. 2002. A quantitative analysis of Spanish indirect object doubling. In James F. Lee, Kimberly Geeslin \& Joseph Clancy Clements (eds.), Papers from the 4th Hispanic Linguistics Symposium, 193-211. Somerville MA: Cascadilla.

Llorente Maldonado de Guevara, Antonio \& José Mondéjar. 1974. La conjugación objetiva en español. Revista Española de Lingüistica 4: 1-60.

Marcos Marín, Francisco. 1978. Estudios sobre el pronombre. Madrid: Gredos.

Melis, Chantal. 1998. Sobre la historia sintáctica del verbo gustar. In Actas del IV congreso internacional de Historia de la Lengua Española. Vol. II, 295-305. Madrid: Arco Libros.

Montrul, Silvina A. 1996. Clitic-doubled dative 'subjects' in Spanish. In Karen Zagona (ed.), Grammatical theory and Romance languages. Selected papers from the 25th Linguistic Symposium on Romance Languages [Current Issues in Linguistic Theory 133], 183-195. Amsterdam: John Benjamins.

Radtke, Edgar. 1987. A me mi piace als Standardform im Seicento? Zeitschrift für romanische Philologie 103: 370-379.

Real Academia Española. 1973. Esbozo de una nueva gramática de la lengua española. Madrid: Espasa Calpe.

Riiho, Timo. 1988. La redundancia pronominal en el iberorromance medieval [Zeitschrift für romanische Philologie; Beihefte 222]. Tübingen: Niemeyer.

Rini, Joel. 1991. The redundant indirect object constructions in Spanish: A new perspective. Romance Philology 45: 269-286

Silva-Corvalán, Carmen. 1984. Semantic and pragmatic factors in syntactic change. In Jacek Fisiak (ed.), Historical syntax [Trends in Linguistics: Studies and Monographs 23], 555-573. Berlin: Mouton de Gruyter.

Suñer, Margarita. 1999. Clitic-doubling of strong pronouns in Spanish: An instance of object shift. In Jon Franco, Alazne Landa \& Juan Martin (eds.), Grammatical analyses in Basque and Romance linguistics. Papers in honor of Mario Saltarelli [Current Issues in Linguistic Theory 187], 233-256. Amsterdam: John Benjamins.

Torrego, Esther. 1996. Experiencers and raising verbs. In Robert Freidin (ed.), Current issues in comparative grammar [Studies in Natural Language and Linguistic Theory 35], 101-120. Dordrecht: Kluwer.

Torrens, Vincenç \& Kenneth Wexler. 2000. The acquisition of clitic-doubling in Spanish. In Susan M. Powers \& Cornelia Hamann (eds.), The acquisition of scrambling and cliticization [Studies in Theoretical Psycholinguistics 26], 279-297. Dordrecht: Kluwer. 